\title{
Households economically headed by women in times of expansion and crisis (1999-2012): the case of Latin American migrants in Spain
}

Xiana Bueno

Harvard University

Elena Vidal-Coso

Université de Genève

xianabuenogarcia@fas.harvard.edu

Elena.Vidal@unige.ch

Fecha recepción 28.11.2015 / Fecha aceptación 30.05.2016

\section{Abstract}

The arrival of flows of Latin-American females in Spain has been closely linked to the demand for domestic workers and carers. During the last period of economic expansion, a subsequent masculinisation of these Latin American flows was seen, explaining the trend toward greater gender and occupational balance among these families. An economic recession followed, however, and unemployment impacted men more than it did women, as reflected in the rise in the number of women who became the sole breadwinners in their households.

\section{Resumen}

La llegada de mujeres latinoamericanas a España ha estado estrechamente vinculado a la demanda de cuidadoras y trabajadoras domésticas en el mercado laboral. La posterior masculinización de los flujos de inmigración latinoamericanos durante el periodo de expansión económica explica la evolución hacia un mayor equilibrio de género y ocupacional entre estas familias. Sin embargo, con la llegada de la crisis económica, el desempleo afectó a los hombres más que a las mujeres y ello se ve reflejado en el creciente número de mujeres 
Using the Economically Active Population Survey, we explore the nature of these household structures, the changes in relation to the economic context, and the socio-demographic and labour market characteristics. Female-headed households are defined as those nuclear households where women are the only economic providers. The first of two hypotheses was a greater incidence of female-headed households among Latin American migrants than among households headed by exogamous and Spanish couples, irrespective of other socio-demographic characteristics. The second hypothesis predicted a greater incidence of female-headed households during the recent years of economic crisis. Furthermore, we expected this increase to have occurred in all households but to have been particularly high among Latin-Americans. The results confirm the prevalence of Latin American women as female heads of households and the adjustment within families in line with the changing Spanish socioeconomic and migratory context between 1999 to 2012.

\section{Key words}

economic female headship, international migration, economic crisis, Latin Americans, gender, Spain que se convirtieron en únicas proveedoras económicas de sus hogares. A través de la Encuesta de Población Activa exploramos cómo es la estructura de esos hogares, sus cambios a raíz del cambio de contexto económico y sus características sociodemográficas y laborales. Definimos los hogares encabezados por mujeres como aquellos hogares con núcleo en los que las mujeres son las únicas proveedoras económicas. Nuestra primera hipótesis se sustenta en la mayor incidencia de los hogares encabezados por mujeres entre los migrantes Latinoamericanos respecto a los españoles o a aquellos en los que convive una pareja mixta con mujer latinoamericana, e independientemente de otras características sociodemográficas. La segunda hipótesis predice una mayor incidencia de los hogares con jefatura femenina durante el periodo más reciente marcado por la crisis económica. Ese incremento se prevé para todos los hogares, pero se presume mayor entre los latinoamericanos. Los resultados confirman la prevalencia de las mujeres latinoamericanas como jefas de hogar y el ajuste de las familias al cambio de coyuntura socioeconómica y migratoria entre 1999 y 2012.

\section{Palabras clave}

jefatura femenina, migración internacional, crisis económica, Latinoamericanos, género, España. 


\section{Introduction}

The arrival of nearly six million migrants at the beginning of the $21^{\text {st }}$ century turned Spain into a primary immigrant destination. Today, we can state that the rise and fall of immigration flows paralleled the expansion and contraction of the economy in Spain, with the year 2007 having the highest number of arrivals with more than 900,000 registrations. Since that time, Latin American migrants have come to represent $37 \%$ of the total foreign-born population in 2012 according to official population registers. Latin American migrants are a numerically large group, and women, who play an important pioneering role in Latin American migration, thus constitute an interesting case for our study. Compared with other immigrant groups, this specifically gendered feature (approximately $55 \%$ of the resident migrants from Latin America in 2012 are female) accounts for a more specific family migration strategy.

Why have Latin American immigration flows in Spain become highly feminized? Previous research ${ }^{1}$ primarily relates the phenomenon to the existence of an important demand for domestic and care workers, which also explains the high labor participation rates of these women. In fact, historians have broadly documented the intimate connection between the feminization of immigrant flows, both internal and international, and domestic service at least since the early modern period ${ }^{2}$. Although this applies to most immigrant women in Spain, it is especially relevant to Latin American women, who are preferred in Spain for

1.E. Reyneri, "Immigrants in a segmented and often undeclared labour market". Journal of Modern Italian Studies, 9(1), 71-93. 2004. F. Anthias, \& G. Lazaridis, "Gender and Migration in Southern Europe". Oxford: Berg. 2000. C. Solé, "Inmigración, mercado de trabajo y género". Documento de Trabajo, Serie Sociología S2003/01. 2003. L. Cachón, "La "España inmigrante": Marco discriminatorio, mercado de trabajo y políticas de integración”. Rubí (Barcelona): Anthropos. 2009. 66.

2. A. Fauve-Chamoux, "Servants in preindustrial Europe: gender differences", Historical Social Research, 112-129. 1998. J.M. Moya, "Domestic service in a global perspective: gender, migration and ethnic niches". Journal of Ethnic and Migration Studies, 33(4), 2007. 559-579. 
housekeeping and care work because of the shared language and religion ${ }^{3}$. Indeed, historically, employers' preferences and prejudices or linguistic similarities or distances explain even less than relative poverty ${ }^{4}$. Moreover, labor and family strategies of domestic workers have always been connected. If traditionally services were linked to a period of celibacy based on different labor strategies ${ }^{5}$ of either single or widowed to earn and save money and make prospects of marriage and family formation easier ${ }^{6}$. Focusing on the contemporary female immigrant flows in Spain, Oso ${ }^{7}$ noted the importance of pioneering female immigrants engaging in domestic service work to the migration of their household as a first stage of the migratory process before reunification with other family members.

The household composition of Latin Americans in Spain and its evolution over time are highly correlated with Spanish labor market characteristics. In fact, the role of Latin American women as pioneering migrants who were in the process of regularizing their legal status in Spain was especially relevant during the early years of massive immigration. During this first period, immigration from Latin America was a solution to the labor demand for domestic workers and caregivers, explaining the high incidence of women as the primary breadwinners in their households. In the second period, beginning in approximately the mid-2000s, the economic expansion focused on labor opportunities for migrants, and a growing presence of Latin Americans with regular status due to legalization processes, which in turn enabled an increase in family reunifications with husbands and children. Our expectation is that the growing number of family reunifications and the increasing demand for male workers for construction and related industries during the economic boom explain the evolution toward greater gender and occupational balance among Latin American families. However, the economic recession brought important difficulties to these families because the occupational sector in which most immigrant men were employed (i.e., construction) was the most strongly affected by the crisis. Consequently, unemployment has affected men more than women, which is reflected in the growing number of women who have become the sole breadwinner in their households.

Women as head of households have been the focus of research before. Some authors have studied the role of widows and spinsters during the eighteenth and nineteenth cen-

3. A. Izquierdo, "Los preferidos frente a los extranjeros permanentes: La inmigración marroquí en los inicios del siglo XXI”. In B. López García \& M. Berriane (Eds.), Atlas de la inmigración marroquí en España (pp. 112-114). Madrid: Taller de Estudios Internacionales Mediterráneos, 2004.

4. J.M. Moya, "Domestic service..." loc. cit.

5. A. Arru, "The distinguishing features of domestic service in Italy", Journal of Family History, 15(4), 1990. 547-566.

6. A. Fauve-Chamoux, "Servants in preindustrial..." loc. cit.

7. L. Oso, "Las jefas de hogar en un contexto migratorio. Modelos y rupturas". In: Checa, F. (ed.). Mujeres en el camino. El fenómeno de la migración femenina en España. Barcelona: Icaria, 2003. 85-104. 
turies $^{8}$, highlighting the difficult circumstances in which they lived, particularly in periods of economic crisis. Today, in the context of the profound transformations in family structures and a growing and unstoppable role of women in the productive sphere, female-headed households have already become increasingly frequent. Some authors have even identified the female-headed household as a particular family arrangement within Latin American societies. Some Latin American authors have emphasized that personal relationships and births outside of marriage have been widespread since the period of Catholic colonialism in the Americas, causing single motherhood to be a common family situation ${ }^{10}$. Moving to the Spanish context in which the economic crisis increases the vulnerability of the migrant population, the study of female headship leads us to some interesting research questions. Are Latin American households in Spain more prone to be economically headed by women than Spanish or mixed households? How have Latin American economically female-headed households evolved in Spain in the changing socio-economic environment? Has the eruption of the current economic crisis increased the prevalence of this type of household?

Previous discussions in the literature have shown that there is no standard definition of «head of household». Sometimes, the term refers to economic heads of household, but it can also refer to de facto heads of household (i.e., the male or the oldest member), whereas in censuses and surveys, this information is often self-reported. The meaning of «head» differs depending of the sex to whom it concerns: male heads of household largely refer to households that have a female partner; by contrast, female heads are traditionally associated with a lack of male partner and the presence of dependent children ${ }^{11}$. Being aware of the debate on the definition of «household» and «head of household» in previous studies ${ }^{12}$, we opt for an economic definition. Thus, we use the term «female-headed household» or «matrifocal household» to refer to all those households (except for single-member households) in which the sole breadwinner or breadwinners are women; that is, all employed household members

8. O. Hufton, "Women without Men: Widows and Spinsters in Britain and France in the Eighteenth Century." Journal of Family History 9 (4). 1984. 355-76. M. Palazzi, "Female Solitude and Patrilineage: Unmarried Women and Widows During the Eighteenth and Nineteenth Centuries." Journal of Family History 15 (1): 1990. 443-59

9. S. De Vos, "Latin American households in comparative perspective". Population Studies, vol. 41, núm. 3. 1987.

10. N. Folbre, "Women on their own: global patterns of female headship", in Rita S. Gallin y Anne Ferguson, The women and international development annual, vol. 2, Westview Press, Boulder. 1991. J. Quilodrán, “Quand l'union libre n'est pas un phénomène nouveau”. Cahiers Québecois de Démographie, vol. 28, n. ${ }^{\circ} 1-2.1999 .53-80$.

11. S. Rosenhouse, "Identifying the poor: is headship a useful concept?", trabajo preparado para la Joint Population Council/International Center for Research on Women Seminar Series, febrero 27-28, Washington, D.C. 1989.

12. M. Buvinić, \& G. Rao Gupta, G. "Female-Headed Households and Female-Maintained Families: Are They Worth Targeting to Reduce Poverty in Developing Countries?” Economic Development and Cultural Change, Vol. 45, No. 2, 1997. 259-280. 
are female members who economically support the other members. Thus, our definition of «female-headed household» covers not only single-mother households, as much of the literature traditionally does, but also couples with and without children as well as extended and multinuclear households. Moreover, «single-mother households» must be understood in the context of international migration beyond the statuses of single motherhood, separated, divorced or widowed because these households can also include transnational female headships in which women have been the pioneering migrants.

Using the Spanish Labor Force Survey (SLFS), we aim to highlight the presence of female-headed households within the Latin American community and their families' adjustments to the changing Spanish socioeconomic and migratory context from 1999 to 2012. We cover the economic expansion period from 1999 until 2007 as well as the current economic constraints from 2008 to 2012. In the first stage of the analysis, we describe these household structures, how they change in parallel with the socio-economic context, and the socio-demographic and labor market characteristics of the women who are the heads of their families. Additionally, we observe different potential patterns by origin, especially compared with the Spanish population. In a second stage, using multivariate analysis, we explore the likelihood of being female head of households of Latin-American women compared to Spanish-born women, during the years of economic expansion and recession and controlling for several socio-demographic and migration characteristics.

The primary contributions of our research are as follows. This study conducts the first quantitative analysis that focuses specifically on Spain's changing socioeconomic environment as an important determinant of household arrangements for Latin American women in Spain. Our analysis covers the period of economic expansion and crisis, and we test the emergence of a new profile of female-headed households beyond single-motherhood families.

\section{Background and research hypothesis: the emergence of the female breadwinner}

Over the past few decades, family models have experienced important transformations. The male breadwinner model has been the normative family model for a long time ${ }^{13}$. Today, this traditional division of work is becoming obsolete for many postindustrial Western societies in which women have entered in the productive sphere, thus generating more egalitarian couples ${ }^{14}$. The empowerment of women resulting from their expanded access to education and increased labor force participation, the normalization of separation and divorce, and the changing perceptions of single motherhood and non-marital cohabitation are key referents

13. G.S. Becker, “A Treatise on the Family”. Cambridge: Harvard University Press. 1982.

14. P. McDonald, "Societal foundations for explaining fertility: Gender equity”. Demographic Research, 28(34). 2013. 981-994. 
for these changes and are framed within the theory of the Second Demographic Transition ${ }^{15}$. Given that dual-earner families have now become widespread ${ }^{16}$, a new model is emerging: the female breadwinner mode ${ }^{17}$. Previous studies in the US have focused on the role of women as the sole or main earners in households ${ }^{18}$. It has been estimated that one in four US households ${ }^{19}$ and one in six French household $s^{20}$ have female breadwinners.

There is another important body of existing literature that has traditionally studied «female-headed households» as households with dependent children headed by unmarried, separated, divorced or widowed women in contrast to «two-parent households». In the context of three decades ago, female-headed households were studied as «incomplete families» because of the lack of male breadwinner ${ }^{21}$. Most previous literature focused on the economic and labormarket disadvantages that cause a higher level of poverty and its implications for the social and economic well-being of these women and their children. This adverse position and the higher vulnerability of female-headed households have been widely studied in the US ${ }^{22}$. Related studies have been concerned with the transition from single-mother households to extended households in balancing the lack of male members ${ }^{23}$, the stress levels of women who are economically responsible for their households ${ }^{24}$ or the role of non-nuclear family members in female-headed households in facilitating mothers' labor market participation ${ }^{25}$.

15. D. Van de Kaa, "Europe's second demographic transition". Population Bulletin, vol. 42, n. ${ }^{\circ} 1,1987$. $1-59$.

16. H.P. Blossfeld, \& S. Drobnic, (Eds.) "Careers of Couples in Contemporary Society: From Male Breadwinner to Dual-Breadwinner Families”. Oxford, 2001.

17. V.K. Oppenheimer, "Women's rising employment and the future of the family in industrial societies". Population and Development Review, 1994. 293-342.

18. R.T. Brennan, R.C. Barnett, \& K.C. Gareis, "When she earns more than he does: a longitudinal study of dual earner couples". Journal of marriage and family, 63(1). 2001. 168-182.

19. Wang, W., K. Parker, and P. Taylor. Breadwinner Moms. Pew Research Center (2013): 1-28.

20. H.G. Bloemen, \& E.G. Stancanelli, “Toyboys or supergirls? An analysis of partners' employment outcomes when she outearns him". Review of Economics of the Household, 2013. 1-30.

21. M. Tienda, \& S. Ortega Salazar, "Las familias encabezadas por mujeres y la formación de núcleos extensos: una referencia al Perú”. Demografía y economía, Vol. 16, No. 1, 1982. 64-89.

22. M. Tienda, \& J. Glass, "Household Structure and Labor Force Participation of Black, Hispanic, and White Mothers”. Demography, Vol. 22, No. 3, pp. 381-394. 1985. Buvinić \& Rao Gupta, 1997, Loc. Cit. D. Lichter, D.K. McLaughlin, \& D.C. Ribar, "Welfare and the Rise in Female-Headed Families". American Journal of Sociology, Vol. 103, No. 1, 1997. 112-143.

23. M. Tienda, \& S. Ortega Salazar, "Las familias encabezadas..." Loc.Cit.

24. S. McLanahan, "Family Structure and Stress: A Longitudinal Comparison of Two-Parent and FemaleHeaded Families". Journal of Marriage and Family, Vol. 45, No. 2, 1983. 347-357.

25. A.R. Snyder, D.K. McLaughlin, \& J. Findeis, "Household Composition and Poverty among FemaleHeaded Households with Children: Differences by Race and Residence”. Rural Sociology 71(4), 2006, $597-$ 624. 
There is a large body of literature ${ }^{26}$ addressing the social and economic vulnerability of female headship and the feminization of poverty in Latin American countries ${ }^{27}$. Femaleheaded households represent a significant proportion of household arrangements in this region $^{28}$. Indeed, the proportion of out-of-wedlock births has been historically higher in Latin America than in Western countries ${ }^{29}$. In this sense, other authors have suggested that women in consensual unions are more likely to be household heads than married women because the former have less stable economic support from a male partner ${ }^{30}$. Female heads have been reported to be concentrated in the late stages of the life course; to live in extended living arrangements; to have smaller average household size than male-headed households; and to have higher labor force participation, especially for migrant women ${ }^{31}$. Early studies in Argentina showed a concentration of these women in less-qualified job positions living with their children alone or in complex structures as well as in households without a nucleus ${ }^{32}$.

Focusing on migrant women as heads of household, $\mathrm{Oso}^{33}$ discussed the state of the art of this specific body of literature. The author describes how the literature on this topic has recently captured the interest of academics beyond the role of men as pioneering migrants and migrant women as regrouped partners. She concludes that although we can consider women to be breadwinners, most of the literature has focused on their role in the reproductive sphere and in shaping family dynamics focusing on topics like transnational maternity, child wellbeing, family reunification and the reproduction of gender roles in the labor market ${ }^{34}$. It is

26. For a detailed state-of-the-art discussion on female-headed households in Latin America, the Caribbean and Mexico, see Acosta (2001)

27. F. Acosta Díaz, "Jefatura de hogar femenina y bienestar familiar: resultados de la investigación empírica", Papeles de Población, vol. 7, núm. 28, abril-julio, 2001. M. Buvinić, "La vulnerabilidad de los hogares con jefatura femenina: preguntas y opciones de política para América Latina y el Caribe", Comisión Económica para América Latina y el Caribe. 1990. M.C. Cacopardo, A. Maguid, \& R. Martínez, "La nueva emigración de latinoamericanos a España: el caso de los argentinos desde una perspectiva comparada". Papeles de Población, vol. 13, núm. 51, pp. 9-44. 2007. B. García, \& O. Oliveira, "Mujeres jefas de hogar y su dinámica familiar". Papeles de población, n43, 2005. 29-51.

28. S. De Vos, "Latin American households..." Loc. Cit.

29. T. Castro Martín, "Maternidad sin matrimonio: nueva vía de formación de familias en España”. Madrid: Fundación BBVA, Documento de Trabajo 16, 2007. http://www.fbbva.es/TLFU/dat/dt_16_maternidad.pdf. 2007.

30. M. Buvinić, NH Youssef, \& B Von Elm, "Women headed households. The ignored factor in development planning”, Office of Women in Development, U.S. Agency for International Development, Washington, D.C., International Center for Reaserch on Women (ICRW). 1978.

31. F. Acosta Díaz, "Jefatura de hogar femenina..." Loc. Cit.

32. M.C. Cacopardo, "Jefas de hogar de ayer y de hoy en la Argentina”. Papers de Demografia, nº 150. 14 1999.

33. L. Oso, "Migracíon, género y hogares transnacionales", La inmigración en la sociedad española: una radiografía multidisciplinar" / coord. por Joaquín García Roca, Joan Lacomba, Barcelona: Ediciones Bellaterra, ISBN 978-84-7290-407-1, 2008. 561-586.

34. L. Oso, "La migración hacia España de mujeres jefas de hogar". Ministerio de Trabajo y Asuntos Sociales. Instituto de la Mujer. No 52. Madrid. 1998. M.L. Santos Pérez, "Mujeres ausentes y cabezas de 
worth noting that migrant female headship concerns not only co-residence at the household level but also transnational families in countries of origin that are economically supported by remittances from emigrated women, representing a different type of headship. Some authors have shown that transnational female heads generally send more remittances to their kin in origin countries than transnational male heads ${ }^{35}$. Similar results have been found for the specific case of Latin American migrants in Spain, highlighting the greater family commitment of female heads to their relatives in their country of origin over longer durations, especially when young children are involved ${ }^{36}$.

Domestic services, female immigration and labor and family strategies have been connected in many parts of the world over the last two centuries ${ }^{37}$. Rural migrants comprised a vast majority of domestic servants, whereas the connection between international movements and domestic service is becoming intense as domestic service today relies on global inequalities ${ }^{38}$. The linkage between domestic work and life course has also been strong, even if the strategies have evolved. Historically, care services were linked to a period of celibacy ${ }^{39}$. Indeed, some authors ${ }^{40}$ explained for the pre-industrial cities, that a high number of women with no spouse either single or widowed migrated to urban areas working in these services to easily get married and form a family. However, these family plans were not always fulfilled due to the increased unbalanced sex ratio. This could explain why among female servants heading their households in Santiago de Compostela by 1860, only $42-48$ per cent were in nuclear families, and that almost all the rest were living alone, and around 30 percent were widows.

The feminization of Latin American migration to Spain has also been widely studied and its mechanism are close to those just mentioned. Efectively, the prevalence of female migration to Spain has been linked to the labor market demand in specific occupational sectors, such as domestic work and care-giving, just as both members of Spanish couples were simultaneously becoming active in the labor market, and consequence of an ageing population ${ }^{41}$. Moreover, Latin American female-oriented inflows have been related to a specific labor and

familia: realidades sociales y económicas de las familias transnacionales constituidas entre Colombia y España”. Final report Carolina Foundation. Madrid. 2011.

35. A. Canales, "El papel de las remesas en la configuración de relaciones familiares transnacionales", Papeles de Población, vol. 11, núm. 44, abril-junio, 2005, 149-171. J. Lauby, \& O. Stark, "Individual migration as a family strategy: young women in the Phillippines", Population Studies, vol. 42, núm. 3. 1988. S.R. Curran, \& E. Rivera-Fuentes, "Engendering migrant networks: the case of Mexican migration", Demography, vol. 40, núm. 2. 2003.

36. R. Grande, \& L.A. Del Rey-Poveda, "Remesas, proyectos migratorios y relaciones familiares. El caso de los latinoamericanos y los caribeños en España”, Papeles de Población, vol. 18, núm. 74, octubre-diciembre, 2012, 237-272.

37. J.M. Moya, “Domestic service...” loc. cit. A. Fauve-Chamoux, "Servants in preindustrial..." loc. cit.

38. J.M. Moya, "Domestic service..." loc. cit.

39. Arru, 1990 Loc. Cit.

40. A. Fauve-Chamoux, "Servants in preindustrial..." loc. cit.

41. Vidal Coso, E.; Gil Alonso, F.; Domingo, A. (2009), “The Non-EU-25 Female Population in Spain: A Factor Analysis of Labour Market Integration at Regional Level”, a Kuhn, M. and Ochsen, C. (eds.), Labour 
family strategy that has become more prevalent in complex households without nuclei ${ }^{42}$. However, this doesn't necessarily mean that these women arrived to Spain prior to marriage and family formation. After analyzing the temporal relationship between family and migration experience for Latin-American women migrated to Catalonia during the recent decades, Vidal-Coso and Bueno ${ }^{43}$ concluded that most of them were already in partnership and had their children before the migration to Spain.

Despite a breadth of literature on migrant living arrangements and economic headship transitions, the role of economic recessions and their influence on these arrangements and transitions have been understudied. Research has suggested that, in the US context, recession leads to a decline in new households ${ }^{44}$ as well as a tendency for household types to become more complex among migrant groups ${ }^{45}$. This finding has also been confirmed for Latin Americans in Spain ${ }^{46}$. Studies have also found higher unemployment rates for men in the US during the 2008 recession ${ }^{47}$. Likewise, the ways in which the economic crisis in Spain has affected (Latin American) migrants are especially relevant for this study. Unemployment has dramatically affected traditionally male occupational sectors (i.e., construction) rather than female-dominated sectors (i.e., domestic work, caregiving) in the context of a highly segregated labor market ${ }^{48}$. Within this context, some authors have recently confirmed a «feminization» of job stability among foreign women in $\operatorname{Spain}^{49}$. This finding reinforces our working hypotheses.

In this paper, we first aim to emphasize the specific role of Latin American immigrant women in Spain who are economically responsible for their households. Our first hypothesis is that the probability of Latin American women, particularly those with a Latin American partner, becoming the head of household is higher than the probability of Spanish women

Markets and Demographic Change, Demographischer Wandel - Hintergründe und Herausforderungen, Rostock: VS Research, VS Verlag für Sozialwissenschaften, 210-233.

42. A. Domingo, \& A. Esteve, "Género, ocupación y estructura el hogar de la migración dominicana y ecuatoriana en España y Estados Unidos”. America Latina Hoy, Vol. 55, 2010. 41-60.

43. E. Vidal-Coso \& X, Bueno, "Les altres catalanes: formar família abans o després de la migració", in Domingo, Andreu et al. (eds.) Recerca i Immigració VII. Migracions dels segles XX i XXI: una mirada candeliana. Generalitat de Catalunya. Departament de Benestar Social i Família. 2015.

44. G. Painter, "What Happens to Household Formation in a Recession?" Research Institute for Housing America, Special Report. 2010.

45. P. Taylor, J. Passel, R. Fry, R. Morin, W. Wang, G. Velasco, D. Dockterman, "The Return of the MultiGenerational Family Household”. Pew Research Center. 2010.

46. H. De Valk, \& X. Bueno. "Living Arrangements, the Crisis and Mother's Participation in the Labor Market” In Domingo, A., Sabater, A. and Verdugo, R. (Ed.) Demographic Analysis of Latin American Immigrants in Spain, Applied Demography Series 5. Springer International Publishing, 2015. 155-180.

47. Y. Cho, \& D. Newhouse, "How Did the Great Recession Affect Different Types of Workers? Evidence from 17 Middle Income Countries". World Development, 41: 2012. 31-50.

48. L. Cachón, "Inmigración y segmentación de los mercados de trabajo en España”. Sevilla, 2003.

49. N. Zugasta, "Incidencia de la crisis en el empleo extranjero. Evidencias a partir de las transiciones laborales de trabajadores indefinidos". Papers 99/2, 2014. 285-306. 
becoming head of household independent of the socio-economic context and other sociodemographic features, such as age, educational level, occupation, and family characteristics. This hypothesis is based on the relevance of these women to labor flows and the smaller social network of support that characterizes migrant populations compared with networks for native women. Our second objective is to highlight the consequences of Spain's changing socioeconomic and migratory context from 1999 to 2012 for Latin American women's household arrangements. During the first part of the period analyzed (1999-2003), we expect to find a high prevalence of Latin American women serving as head of household because of the high number of pioneering immigrant women who recently arrived in Spain based on the labor demand for domestic workers and caregivers. However, we predict that these women will have a lower probability of becoming the economic heads of their household during the 2004-2007 period as a result of the growing number of family reunifications and the increasing demand for male workers in construction and related industries during the economic boom. Finally, we hypothesize that women are more prone to be the sole breadwinner in their households during the current economic crisis. This increase in female-headed households is driven partly by nuclear families (couples with or without children) in which the male partners became unemployed and partly by the greater number of single-mother households as well as separations, divorces, and husbands' return migration.

3. Data and Methods

The data for this study are obtained from the 1999-2012 Spanish Labor Force Survey (SLFS). Several reasons justify the use of the SLFS as the best choice for this analysis. First, this survey contains broad information on an individual level related to the socio-demographic and labor characteristics of the population in the reference week (previous week) such as sex, age, and employment status. Second, although the survey was designed to analyze the labor market from 1999 onward, it is also a unique source for studying yearly household composition and the characteristics of household members in the inter-census period. Third, the SLFS also collects rich information regarding the immigrant population such as citizenship, country of birth and length of residence. Fourth, the quarterly frequency of the survey facilitates analysis of the influence of the economic context on the employment status of Latin American household members and their living arrangements. Being its weakness for this purpose that SLFS is not a source focused on immigrant population or migration processes, it is conversely the unique source that allows observing households quarterly during the expansion and crisis period.

The SLFS is a rotating panel in which $1 / 6$ of the sample is removed in each wave, leaving $5 / 6$ remaining in the sample. To avoid overlap in participants in the survey we select one survey every six trimesters starting from the first trimester of 1999 until the last available in 2012.

Results have been organized in two sections: a descriptive and a multivariable approach. Within the descriptive analysis, we first take households as level of analysis to explore how female-headed households' living arrangements are and how they change in parallel with the economic context. Later, on the individual level, we look at which socio-demographic and labor market characteristics have the women as well as different patterns by country of origin, in comparison to the Spanish population. The multivariable analysis is aimed to test 
the effect of country of birth and the changing socio-economic context on female headship. We first run a pooled binary logistic regression model in which both Spanish-born and Latin American born women are included in order to test the higher probability of the latter to head their households. We later run separate models by origin to explore how individual and familial characteristics explain differently the likelihood of being the unique provider of their households. The analysis also allows measuring the impact of the economic crisis on living arrangements, as well as of other migration characteristics when only Latin-American women are considered. The sample for all these models is limited to married or cohabiting women between the ages of 16 and 64 .

To explore differences by origin at the household level, we have grouped households into 3 types according to the country of birth of all adult members aged between 16 and 64 years old (thus, we do not consider descendants of first-generation migrants who might be born in Spain): 1) Latin American households; 2) mixed households (i.e., a woman born in Latin America in union with a Spanish-born male, Latin Americans living with household members older than 16 who were born in Spain); and 3) Spanish households. Those households in which Latin Americans are cohabiting with immigrants from a third country have been excluded from the analysis because of their small representation. Please note that we have excluded those households without nuclei and those with a single member.

Our final sample for the period 1999-2012 covers a total of 299,401 households with 999,323 individuals (excluding those households without nucleus and those where a single person lives). In 12,898 of these households lives at least one adult born in a Latin-American country. Among these households, $47.9 \%$ have all adult members born in Latin-America, $49 \%$ are comprised of adults from Latin-America and Spain, and only 3.1\% of households are made up of families in which Latin-American adults live with immigrants from other origins. As mentioned, we have not considering the last ones in our analysis due to its small size.

\section{Evolution of household headship in Spain}

Previous literature has highlighted female-headed households as a frequent living arrangement in Latin America. Do Latin American migrants maintain similar patterns in destination countries? In our sample, among households in which all adult members were born in Latin America, approximately $24 \%$ were economically female-headed. This proportion represents $20 \%$ of mixed-origin households but only $12 \%$ of Spanish households. If we consider its evolution during the observed period (Figure 1), we observe how a larger increase in the proportion of female-headed households occurs in Latin American families, from 16\% to $29 \%$ between 2005 and 2012. This rise in the proportion of households economically supported by women generally parallels a decrease in the proportion of households in which only men work, but the trend is especially related to the decrease in the proportion of families in which both men and women work. The same pattern is true for mixed and Spanish households, although the prevalence is lower for these groups, and the tempo is different. Although the significant increase in female-headed households begins in 2008 with the economic crisis for Spanish and mixed households, Latin Americans are already characterized 
by higher proportions of female headship in 2005 (before the crisis began). Therefore, these results highlight the importance of the gender component of Latin American immigration during the expansion period. This finding also explains that Latin American female-headed households are not merely a phenomenon resulting from the economic crisis because they have represented higher proportions throughout the entire period.

FIGURE 1: Evolution of households with at least one adult aged 20-64 by country of birth of its adult members according to household headship

Latin-American household

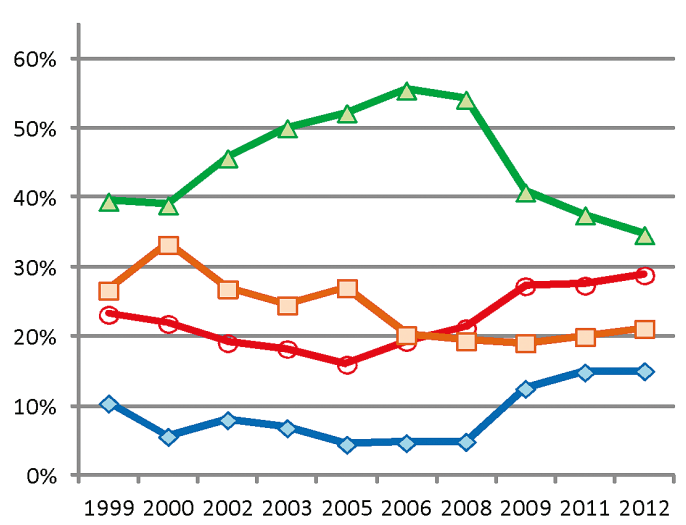

Spanish household

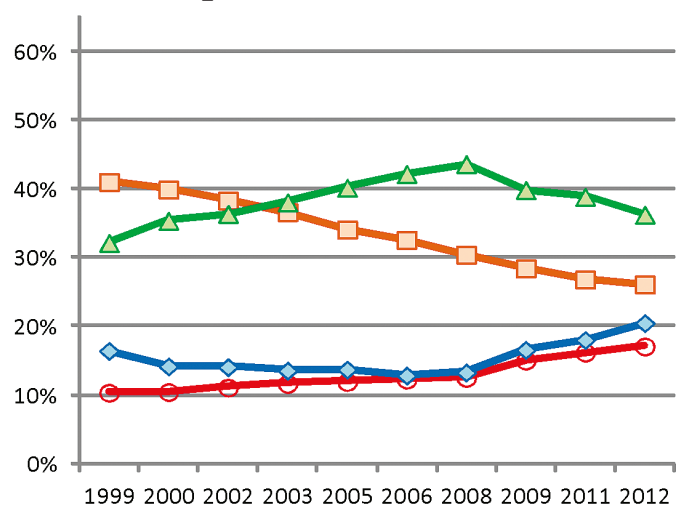

Mixed household

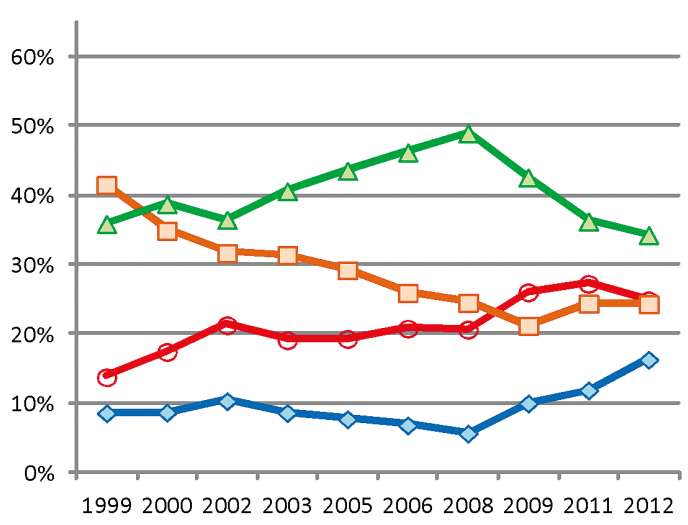

Source: Spanish LFS, 1999-2012

It is also remarkable and concerning that the significant increase in the percentage of households in which all of the adult members of working ages (20-64 years old) were unemployed or inactive is a clear consequence of the economic recession after 2008. Households 
maintained only by men experienced a continuous decline throughout the entire period. This result can be explained by the increasing participation of women in the labor market during the economic expansion ${ }^{50}$. However, once the recession begins, this decline results from the combination of the still-higher rate of female labor force participation and the increasing unemployment rates for men. Moreover, although the effect of the crisis on economic arrangements affects all households, it is more notable among Latin American and mixed couples.

Figure 2, shows the evolution of female-head households by type of living arrangement. We have chosen the year 2000 as the starting point of the immigration boom in Spain, the year 2006 as a vital moment of economic expansion and the reception of international migration inflows, and the year 2012 when the economic crisis was in full force. Heterogeneity is higher in mixed-origin and Latin American households, especially for extended living arrangements and compared with Spanish households. This result is consistent with previous studies that have noted the higher propensity of migrants to live in complex household structures and to rely more on family and social networks of support based on economies of scale and the idea of sharing living costs. This pattern is found especially among recent migrants and has been documented for the case of Latin American migrants in Spain ${ }^{51}$.

FIGURE 2: Evolution of female-head households by type of living arrangement and country of birth of all adult members
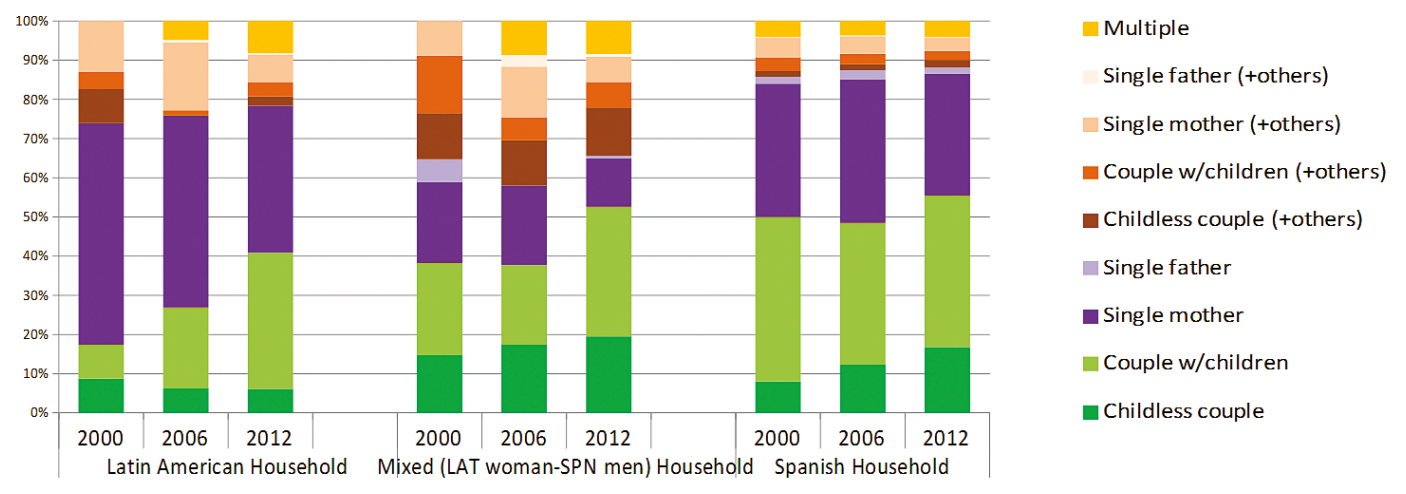

Source: Spanish LFS, 1999-2012.

50. E. Vidal-Coso, \& D. Vono, "Equilibrios ocupacionales en los hogares de latinoamericanas en España durante las etapas de expansión y de crisis económica, 1999-2011" in Cosio-Zavala, Maria Eugenia; Rozee, Virginie, (eds.) Género en movimiento: familias y migraciones, México, Publicaciones El Colegio de México. 2014. Pp. 161-192.

51. X. Bueno \& H. De Valk, “Arreglos familiares de los inmigrantes latinoamericanos en España. ¿Cambios en tiempos de crisis?”. Notas de Población, nº 102, 123-148pp. 2016. 
Among female-headed Latin American households, there has been a significant decrease in the proportion of single mothers living with or without other people (from a total of $70 \%$ of households in 2000 to $45 \%$ in 2012) and an important increase in the proportion of households of couples with children (from $9 \%$ to $35 \%$ ). This new profile of female-headed households might be the consequence of increasing family reunifications and new unions during the period of economic expansion and might result from an increase in the number of households in which the male partner is unemployed because of the economic recession.

\section{Female heads of household in Spain: socio-demographic characteristics}

At this point of our analysis, we shift from the household to the individual perspective to analyze the socio-demographic characteristics of female breadwinners. Compared with other immigrant groups in Spain, the share of female heads among Latin American women is undoubtedly clear, which indicates that this higher share is a specific feature of this origin group rather than a common feature of all immigrant groups. Thus, $21 \%$ of women born in a Latin American country are head of household. This proportion is compared with $15 \%$ of European women in Spain and is nearly double that of native (12\%), African (11\%) and Asian (10\%) women in Spain. However, even among Latin Americans, we can observe striking differences according to the country of birth of these women (Figure 3). Origins in the Andean countries-especially Bolivia but also Peru, Colombia and Ecuador-and the Dominican Republic show the highest proportions of women as head of household. By contrast, for other countries in South America-Venezuela, Brazil, Uruguay and Argentina-and for Cuba, we found a lower proportion of female breadwinners-approximately $12 \%$, which differs little from native levels.

Moreover, it is worth noting that the great majority of these female economic breadwinners do not share their headship positions with other women in their households. The proportion ranges from $78 \%$ of Latin American households to $89 \%$ and $87 \%$ for mixed and Spanish households, respectively. In other words, the proportion of women living in households supported by two or more women is double for Latin American households (22\%) relative to mixed (11\%) and Spanish (13\%) households (not shown in the figures). Considering the country level, we again observe the two previously mentioned patterns for Andean and non-Andean countries, with more multiple female headships in households with origins in Andean countries and the Dominican Republic. 
FIGURE 3: Country of birth of women 16-64 years old by their role as female head of household for the top 10 Latin American countries
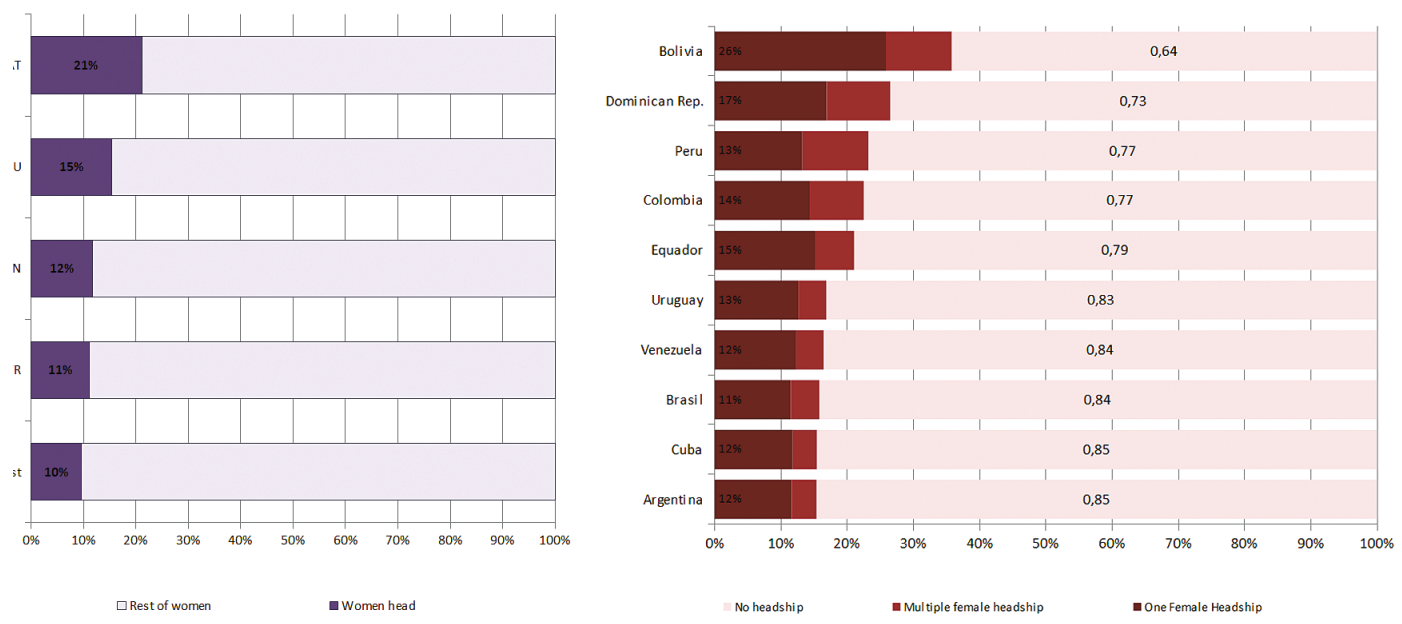

Source: Spanish LFS 1999-2012

Past studies of Latin American countries have remarked that female heads were more concentrated in the later stages of the life course, which is expected, as they primarily refer to separated, divorced and widowed women. In the current study, the approach is different because of our economic definition of headship and because migrants are by definition selected and characterized by a much younger age structure compared with the native population. Figure 4 shows this difference, indicating that the age distribution of Latin American female heads is younger and more concentrated for Latin Americans than for Spanish headships. The migration effect is indeed clear when we examine the later ages-women in their fifties and sixties-for whom the levels of headship are much higher among Spanish women. 
FIGURE 4: Age distribution of women 16-64 years old by their role as female head of household for native Spanish and Latin Americans

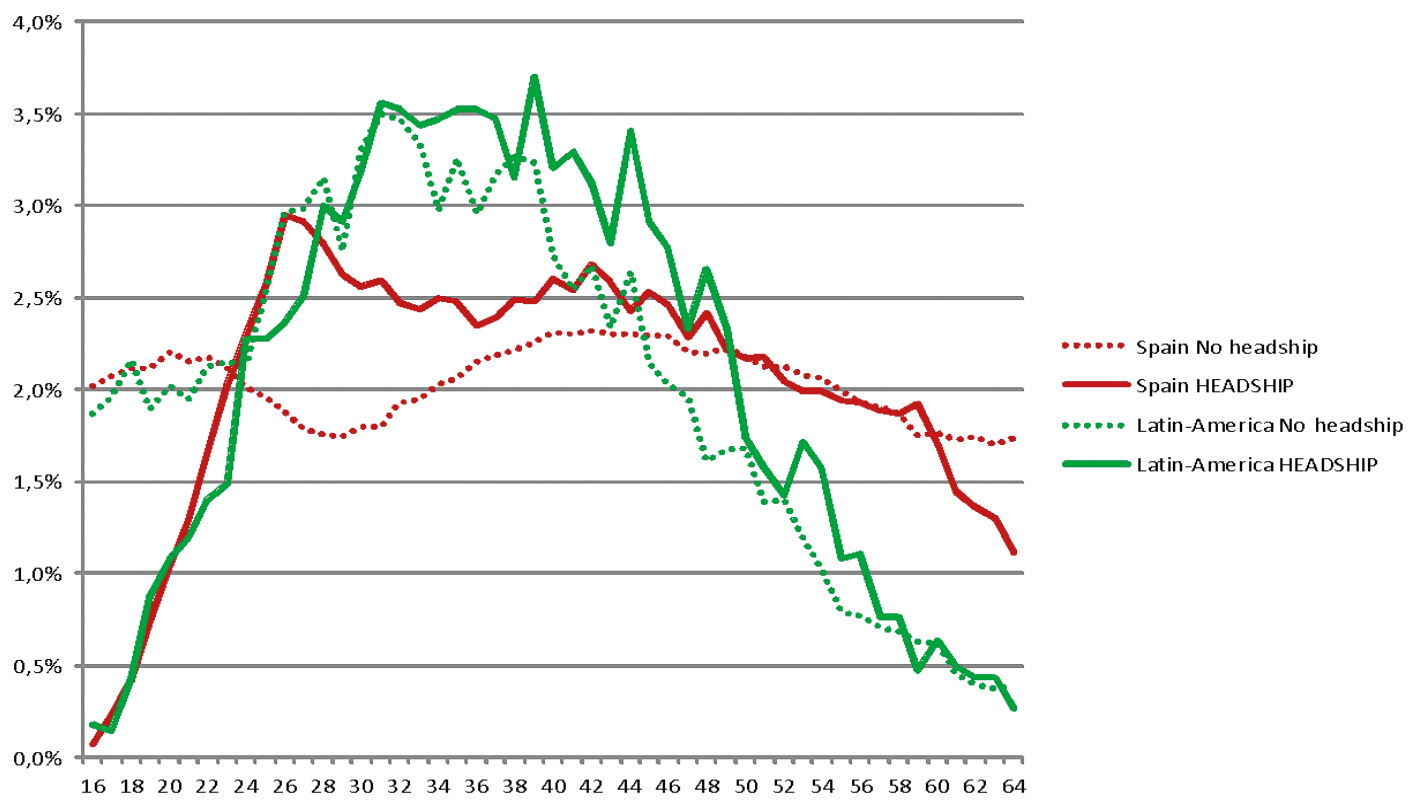

Source: Spanish LFS, 1999-2012

With respect to the labor force characteristics of these women, another important feature that differentiates Latin American female heads from native female heads is the occupational categories in which women are employed. Are female breadwinners of Latin American origin and those of Spanish origin working in the same job positions? Figure 5 provides insight into this question. First, the data show that Latin American women who are economically heading their households are much more concentrated in jobs in the lower part of the occupational scale. The most common occupation is domestic service (25\%), but cleaning, the hotel industry, and personal care are also common occupations. Second, we find a dual occupational distribution among the Spanish female heads. These women have greater presence in some of the top highly qualified occupational sectors, especially in technical, professional and intellectual occupations (20\%) and in administrative and secretarial occupations $(10 \%)$. However, a significant percentage of these women are employed in the most lowskilled and feminized jobs, such as building cleaning (14\%) and personal care (11\%). 
FIGURE 5: Occupational distribution of female heads of households aged 16-64 by origin

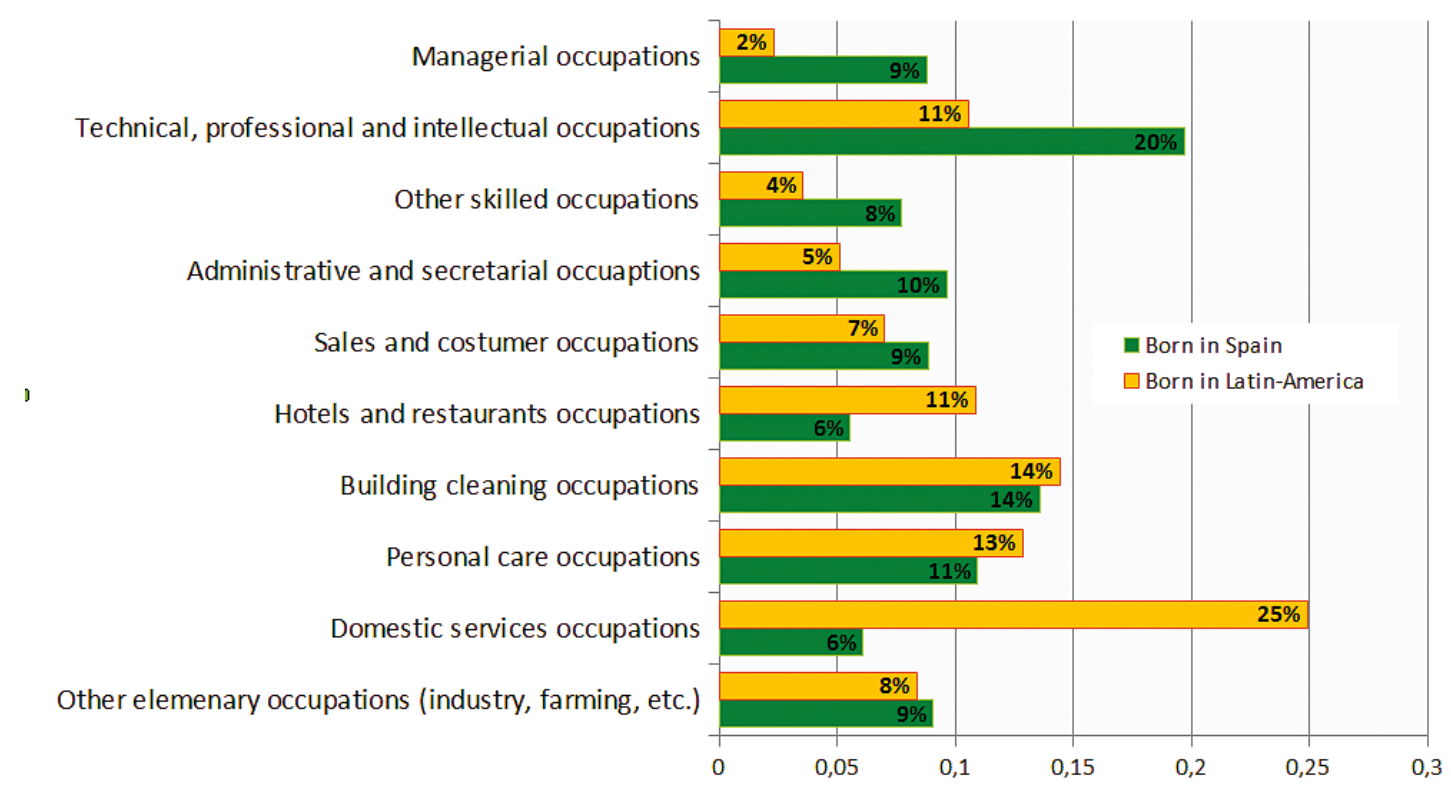

Source: Spanish LFS, 1999-2012

\section{Socio-demographic factors influencing the likelihood of female-headship}

After the descriptive approach to female-headed households and its female heads, we continue the analysis from a multivariate perspective focusing only on those women living with their partners and exploring their likelihood for being the unique economic provider of the household or not. Given the growing importance of female headship among women in couples, Figure 6 presents the distribution of Spanish and Latin American women at working ages living with their partners according to their role as sole earners in the household (or not) and according to several individual, household and migration characteristics. First, we must remark that in this subsample, female heads represent $6 \%$ of total Spanish women aged 16-64 who are cohabiting with their partners, whereas that number is $11 \%$ for Latin Americans. Native women are older than Latin Americans, and for both groups, the mean age for a female breadwinner is older than the mean age of women who are not in a head position. Related to the older age structure, educational attainment appears to be lower for Spanish women. With regard to their living arrangements, more than half of female providers are living in nuclear families, while extended and multiple households are more common among Latin Americans than among Spaniards. Considering the migration characteristics of Latin American women, we can highlight three interesting findings: female heads primarily live in households that are not mixed in origin, which largely refers to non-intermarriage-based 
couples; the proportion of Latin American sole earners who arrived in Spain as a pioneering migrant, that is, before her partner (17\%), is double the comparable proportion of women who are not in a head position; and most female breadwinners are long-term migrants (70\% of them have been living in Spain for five years or more).

FIGURE 6: Sample characteristics of women 16-64 years old living with a partner by its role as female head of household for Spanish and Latin-Americans.

\begin{tabular}{|c|c|c|c|c|c|}
\hline & & \multicolumn{2}{|c|}{ SPAN ISH WOMEN } & \multicolumn{2}{|c|}{ LATIN-AME RICAN WOMEN } \\
\hline & & $\begin{array}{c}\text { No headship } \\
(94 \%)\end{array}$ & $\begin{array}{c}\text { Head ship } \\
\quad(6 \%)\end{array}$ & $\begin{array}{c}\text { No headship } \\
(89 \%)\end{array}$ & $\begin{array}{c}\text { Headship } \\
(11 \%)\end{array}$ \\
\hline $\begin{array}{c}\text { Individual } \\
\text { Characteristics }\end{array}$ & $\begin{array}{l}\text { Mean age } \\
\text { E ducation } \\
\quad \text { Primary or less } \\
\text { Secondary } \\
\quad \text { Terciary } \\
\end{array}$ & $\begin{array}{l}45.3 \\
62 \% \\
22 \% \\
16 \% \\
\end{array}$ & $\begin{array}{l}47.7 \\
59 \% \\
23 \% \\
18 \% \\
\end{array}$ & $\begin{array}{l}37.5 \\
37 \% \\
42 \% \\
21 \% \\
\end{array}$ & $\begin{array}{l}38.8 \\
39 \% \\
41 \% \\
20 \% \\
\end{array}$ \\
\hline $\begin{array}{c}\text { Household } \\
\text { Characteristics }\end{array}$ & $\begin{array}{l}\text { Type of household composition } \\
\text { Couple without children } \\
\text { Couple with children } \\
\text { Extended couple without children } \\
\text { Extended couple with children } \\
\text { Multiple }\end{array}$ & $\begin{array}{l}19 \% \\
70 \% \\
2 \% \\
5 \% \\
4 \% \\
\end{array}$ & $\begin{array}{c}34 \% \\
55 \% \\
4 \% \\
4 \% \\
3 \% \\
\end{array}$ & $\begin{array}{c}19 \% \\
55 \% \\
5 \% \\
10 \% \\
11 \% \\
\end{array}$ & $\begin{array}{c}23 \% \\
58 \% \\
4 \% \\
8 \% \\
7 \% \\
\end{array}$ \\
\hline $\begin{array}{c}\text { Chation } \\
\text { Migracteristics } \\
\text { Charactis }\end{array}$ & $\begin{array}{l}\text { Mixed household by origin } \\
\text { No } \\
\text { Yes } \\
\text { Years of residence } \\
\text { Recent migrant (0-1 years) } \\
2 \text { to } 4 \text { years } \\
\text { Five or more years } \\
\text { Unknown } \\
\text { Who migrated first? } \\
\text { Woman } \\
\text { Man } \\
\text { Together } \\
\text { Unknown } \\
\text { Native partner }\end{array}$ & & & $\begin{array}{c}55 \% \\
45 \% \\
\\
9 \% \\
22 \% \\
55 \% \\
15 \% \\
\\
9 \% \\
19 \% \\
24 \% \\
6 \% \\
41 \%\end{array}$ & $\begin{array}{c}65 \% \\
35 \% \\
\\
5 \% \\
17 \% \\
70 \% \\
7 \% \\
\\
17 \% \\
20 \% \\
27 \% \\
3 \% \\
32 \%\end{array}$ \\
\hline
\end{tabular}

Source: Spanish LFS 1999-2012

Subsequently, multivariate analysis was performed using logistic regression models to asses which socio-demographic variables were independently associated with the likelihood for being or not being a unique female breadwinner in the household. In Figure 7 we set the results for separated regression models that have been run first for all women (model 1), and secondly for Spanish and Latin-American women independently (models 2 and 3).

The pooled version (model 1) shows that the likelihood for being a female head of household is significantly higher for women born in Latin-America, after controlling for age, education, type of living arrangement and the year of observation. Considering that sample 
sizes for the two origin groups are very different, the pooled results are conditioned by the weight of the native sample. Therefore, we proceed to run separate models where we might observe their intrinsic differences. At the individual characteristics we find the first significant difference. While Spanish educated women are more likely to be household breadwinners, education appears to be not an important factor for Latin-Americans. This is not surprising given that Latin-American immigration inflows to Spain were headed by women who later on regrouped their partners and those inflows were mainly motivated by labor reasons, therefore it would seem that these women, regardless of their educational level, got a more stable job situation than their counterparts translated in a higher female-headship in times of crisis, as it was previously pointed out. Interestingly, when considering familial or living arrangement characteristics, the likelihood of being a female breadwinner increases when the couple is childless especially for Spanish women. In this sense, the difficulties of maintaining a household with children are obviously higher when there is only a single earner. For LatinAmericans living in extended and multiple households this likelihood is, on the contrary, lower. Our interpretation is that Spanish female breadwinners are more likely to live in complex structures where other residents are expect to be retired non-active households members. On the contrary, members of Latin-American extended and multiple households are usually younger and they are therefore economically active. As a consequence, the likelihood in these cases of being maintained by a unique female provider is much lower in comparison with other living arrangements.

Given the higher propensity of Latin-American immigrants to live in complex household structures, combined with the fact that family networks are often tight, times of economic crisis results in a stronger reliance on the family or social network for support in providing housing and sharing costs of live $\mathrm{e}^{52}$.

With regard to the economic context, model results confirm what descriptive results approached: the economic recession lead into a higher likelihood for being a female-head. Taking 2006 as a reference year, when the Spanish economy was arriving at the end of its expansion period, the likelihood of being a female-breadwinner was significantly lower during the previous years and higher during the recession years. Particularly, Latin-American women are even more likely to be the unique providers than Spaniards during crisis, but their results are not significant during the years of expansion, partly due to the lower immigrant presence at the beginning of the period.

Migration characteristics included as independent variables for model 3, suggest that after controlling for other characteristics, the length of stay is not a significant factor. Besides that, it is interesting to observe how compared with women who migrated together with her partner, those women who migrated first are more likely to be the main earner, while those who migrated after her partner -either for being regrouped of for establish a new relationship in Spain with a Latin-American man-, are less likely to assume the leadership of the household. Moreover, what is highly significant is the lower likelihood of being female-head when

52. Bueno and De Valk, 2016, Loc. Cit. 
getting in union with a native Spanish partner compared with the joint migration of both Latin-American partners. Previous studies already highlighted the lower labor-participation rates of Latin-American women when they are in union with a Spanish men ${ }^{53}$.

Since we are including in the analysis only women who live with a partner, we must remember when analyzing who migrated first to Spain within the couple, that the pioneer migration of Latin-American women are not well represented. As it was previously shown an important proportion of Latin-American households are identified as single mothers even when the partner is still living at the origin country (the facto separation) and not only for single motherhood or separations and divorces.

Being aware of the important differences by origin that are usually hidden behind a continental aggregation, we controlled by country of birth to look at country-level differences. The two-origin patterns observed on descriptive results among Andean and non-Andean countries is partly repeated in the models. Women from non-Andean countries are less likely to be economic providers than women from Ecuador. But once controlled by other variables, women from two of the Andean countries -Colombia and Peru- appears to be slightly less likely than Ecuadorian women. While Bolivia seems to be the unique country whose women have higher likelihood of headship than Ecuadorians, although is not a significant result.

53. A. Domingo, X. Bueno, \& A. Esteve, "El Rapto de las Latinas: Migración latinoamericana y mercado matrimonial en España”. In Cosio-Zavala, M.E. and Rozée Gómez, V. (Coords) Género en movimiento: familias y migraciones. México, 2014. 310. 
Monográfico | Households economically headed by women in times of expansion and crisis (1999-2012)

FIGURE 7: Odds ratio of the likelihood of being female head of household for women 16-64 years old living with a partner.

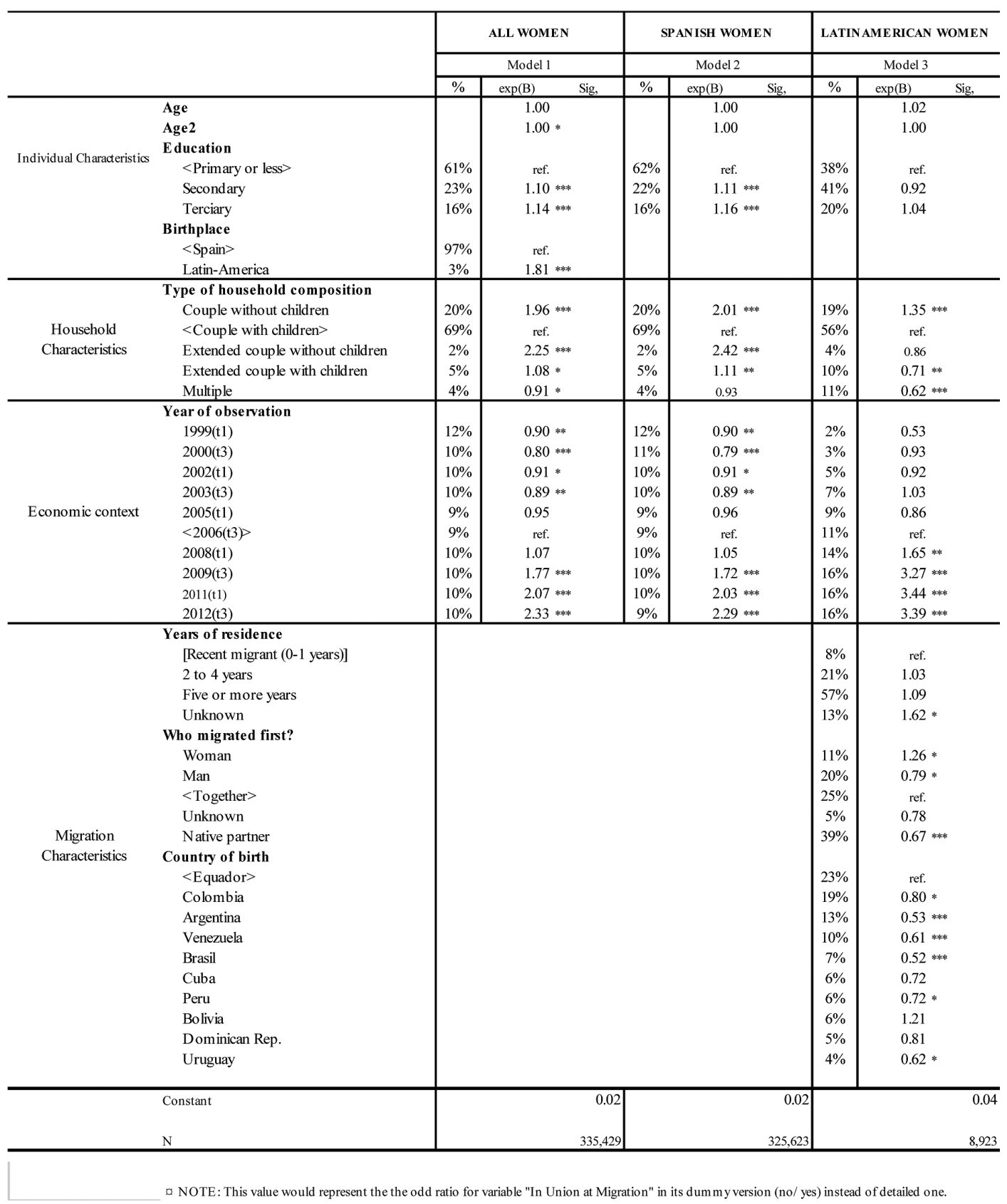

Source: Spanish LFS 1999-2012. 


\section{Conclusions}

Female headship has been traditionally studied in relation to single mothers and separated, divorced and widowed women living with their children, in this paper, we adopt a different perspective to approach the topic on the basis of the economic sustainability of a family structure, that is, with women as sole breadwinners in these households. This economic definition of female headship is emerging in the literature, and our aim is to contribute quantitatively to this research from the perspective of Latin American migrant female heads living in Spain - a topic that has largely been addressed from sociological and qualitative perspectives.

The precariousness and vulnerability of traditional female-headed households have been reported in the past literature for several geographical contexts. Although female-headed households are unfortunately often in a socio-economically disadvantaged situation, this paper has explored, on the contrary, the robustness and strength of Latin American female migrants in Spanish labor market in the context of an economic crisis.

Our aim - to explore the prevalence, evolution, and composition of Latin American economically female-headed households in Spain and their response to the financial crisis-has been adequately addressed through both, descriptive and multivariable analysis. We confirm the undeniable consequences of the crisis that led to an increasing number of households being headed by women as well as households in which no member works (a result that is cause for concern, although it is not our area of interest here). These trends are found for Spanish, mixed and Latin American households; however, for the latter, female headship was a more common economic living arrangement even before the economic recession began, and the rate of female headship continued its rise during and after the crisis. The large numbers of Latin American women who migrated independently to Spain and who often subsequently rejoined their spouses and children represent the primary explanation for this pattern. Once the economic crisis began, we observe an increase in the number of households composed of couples with or without children in which only the woman is employed. The high unemployment rates among male migrants and the more stable job sectors among female migrants (i.e., domestic work, cleaning services, caregiving tasks) explain the better position of women in the labor market compared to their male partners. However, although the expected lower probability of being head of their household for Latin-American women during the peak of the economic expansion is not observed in our models, the effect of the crisis is obvious since 2008,

It is also an interesting result the hidden differences at the country level when we look beyond continental aggregation. We can affirm that the Andean countries (Bolivia, Peru, Colombia and Ecuador) together with the Dominican Republic correspond to the prevalence of a female-head pattern. Meanwhile, other top countries for immigration (e.g., Uruguay, Venezuela, Brazil, Cuba or Argentina) show similar levels of female headship as the Spanish population and other immigrant groups in Spain. In this sense, we must recall that the latter group of countries has important historical links with the former Spanish emigration during the 20th century and currently represent the countries with the highest rates of intermarriage with Spaniards. Thus, a less precarious socio-economic situation can be expected for female 
migrants from these countries in the economic crisis context, as shown by Domingo et al. ${ }^{54}$. Also, the segregated gender pattern on the labor market is stronger among immigrants from Andean countries, meaning that the incidence of male unemployment was higher for them.

This investigation stressed the female headship among the Latin-American immigrant population in Spain in times of economic crisis. When interpreting this contemporary intrafamily economic arrangement, we acknowledge that the connection between the feminization of migration inflows related to the demand for domestic services and a family strategy is not new. In this sense, the paper updated the analysis of a mechanism repeated throughout the industrial era in diverse societal contexts, stressing the specificities of the changing sociodemographic scenario during the period analyzed. Further research in this area is necessary. To obtain a more comprehensive picture of the role of female heads on crisis time the authors are further researching on a longitudinal approach which allows identifying changes on the economic headship structure within the household (i.e. transitions to female headship from double earner, male breadwinner or unemployed couples). We also believe that this work contributes to understanding emerging paths towards new female economic roles, that it might have implications for gender equality in the future.

\section{Acknowledgments}

This work was funded by the projects From complementarity to exclusion? A socio-demographic analysis of the impact of the economic recession on immigrant population (Ref. CSO2011/24501), funded by the Spanish Ministry of Science and Innovation, National R+D+I Plan 2012-2014.

Both authors are team members in the Group for Demographic and Migration Studies, GEDEM (http://gedemced.uab.cat/en/), at the Centre for Demographic Studies in Barcelona (Spain).

54. A. Domingo, et al. "El Rapto de las Latinas..." loc. cit. 